\title{
ANALYSIS OF FOOD SECURITY IN SOUTH TANGERANG CITY, INDONESIA (The ObSTACles of FoOd Security, Agriculture AND FISHERIES)
}

\author{
Iman Lubis, Kholidah Tamami, Dien Mardiana Yulianti \\ Management Department, University of Pamulang, Indonesia \\ *corresponding author: dosen01479@unpam.ac.id
}

\begin{abstract}
The objective of the study is to find the reason for obstacles in food security, agriculture, and fisheries. This research uses primary data and secondary data, such as questionnaires and document literature. Then, we held a focus group discussion to find the real facts. This research uses qualitative research and quantitative research. The schedule of research was between January and July 2019 that Juni 2018 until December 2018 was proposal research. The result is that the six constraints had been designed, but we emphasize three obstacles, which are important that are land, capital, institutional and human resources. The main problem of land is limited land; the bulk problem of institutional and human resources is a decreasing young generation to work in farming, and the problem of capital does not fill the needs. Also, in Focus Group Discussion, the findings of problems are that limited land can be fixed by agreement to Developer; meanwhile, institutional and human resources are still dilemmas because the farmers from years to years decreased. To stimulate them, the agency supports the farmer group competition and seed house, but we all know that it is not enough to increase the quantitative farmer's groups and the role of institutions. Those can be further research.
\end{abstract}

Keywords: Land, Capital, and Human resources

http://dx.doi.org/10.21776/ub.agrise.2020.020.2.3

Received 30 July 2019

Accepted 11 April 2020

Available online 30 April 2020

\section{INTRODUCTION}

The Indonesian government is trying to overcome the problem of meeting food needs by increasing supply through increasing rice production and developing higher-value crops. However, this strategy proved ineffective because even though Indonesia experienced good economic growth, there were still 19.4 million people who could not meet their daily food needs (Ika 2018).

The Indonesian government has formulated the Medium-term Development Plan from 2015 to 2019. The problems food securities in Indonesia are fundamental production, such as a low scale of production, converted irrigated land, low productivity rice field, the limited private sector in producing rice, agricultural production pattern unfriendly environment and climate change; quality of distribution and consumption such as not integrated distribution, unstable staple food reserves and limited the role of National Logistics Agency; quality of food consumption and community nutrition such as invariability health food and the limited role of industry and local government; valueadded, for example, less conducive to invest and lack of industry supporting harvest; downstream such as not clear down streaming policy and land status (Bappenas 2014).

According to Tangerang district studies (Karini 2013), converted the land from paddy fields to nonpaddy fields does not affect total rice production as long as the production process uses agricultural technology and intensification. In West Java, agriculture shows performance in a better direction than fishery (Heryawan et al. 2014). Badami \& Ramankutty (2015) shows that urban agriculture is 
the best to apply in high-income countries, but it will have a limited contribution to poor countries. Following Hamidah et al. (2017), various levels of consumption can be a difference by land characteristics such as high-land, low-land, and a coastal area. High land has the highest consuming protein, and the low-land is higher than the coastal area. Fish consuming patterns are dependent on income either in cities or in rural. The higher income citizens earn, the higher consumption they do (Virgantari et al. 2017).

South Tangerang City is a new city in Indonesia. It has been almost ten years established. For Food Security, South Tangerang City can complete its demand from other cities, but it will make the price of food depend on other places. Maybe, in a short time, if they want to plant, it will be too expensive compared with buying from outside the city. However, in the long term, South Tangerang City will be dependent, and when the demand either increases or in crisis, the prices will be uncontrollable.

We discussing this problem do not focus today that food security is safe. Even South Tangerang City does not have the agriculture sector; they can fill their needs about food, meat, and fishery. We all know if they need foodstuffs, they can contact the area which has surplus and agreement. If they find the difficulties of getting access, they can corporate with police to save the distribution. If the prices increase, the Central Bank of Indonesia (BI) can help to subsidize the foodstuffs. Those solve the problem, but those cannot solve the problem of unproductive farming in a city. It is possible that farming activities are left because the local government has solved the available food security without farming and raising an animal.

In this research, we are interested in exploring the obstacles of food security, agriculture, and fishery if the city farming and raising animals by themselves. The facts declare that the problems of agriculture in a city are limited land, lack of infrastructure, unproductive in farm products, poor production facilities, less implementation of the regulation, less supported institution and human resources, and also investment shortage.

According to Law No. 18 of 2012 Food security has three criteria that are availability, accessibility, and stability. The food can be gotten from everywhere as long the price is stable, and the access is easy. Since the city does not concern to plant by them, researchers are interested in reasoning how the problems or barriers exist.

Agriculture is a type of production process that is typically based on the growth of plants and animals; the farmers regulate and encourage the growth of plants and animals in their farming business (Mosher 1984).
Fisheries According to Law Number 45 of 2009 , Fisheries are all activities related to the utilization and management of fish resources and their environment ranging from preproduction, production, processing to marketing processes carried out in a fisheries business system.

According to Lacket, fisheries can be grouped based on several properties, including:

(1) Fisheries based on the type of environment, for example, freshwater, sea, lake, river, and dams.

(2) Fisheries are based on harvesting methods, for example, trawl fishing, dip net, purse seine, and so forth.

(3) Fisheries based on the type of access permitted, for example, open-access fisheries, open-access fisheries with regulations, and fisheries with limited access.

(4) Fisheries are based on organism concerns, for example, salmon, shrimp, crab, tuna fisheries.

(5) Fisheries based on the purpose of capture, for example, commercial fisheries, subsistence, recreational fisheries.

(6) Fisheries based on the degree of depth of the target animal, total from nature, semi cultivation or total cultivation.

Phillips in Exploring the Future of Indonesian Aquaculture (Phillips et al. 2015) said that Aquaculture is the fastest-growing food production sector in the world. It is estimated that world aquaculture production will double in the next 15-20 years. The growth of aquaculture in the future is the key to providing fish supply in the national, regional and global fisheries system, besides of course it will also absorb a lot of labor; at the same time, keeping fish available at a reasonable level of price for consumers who lack resources.

Production is an activity between the factors of production and the level of production achievement produced, where the factor of production is often referred to as output (Sukirno 2014). In agriculture, production is produced by several factors that affect each other, which are land area, seeds, fertilizers, pests (pesticides), labor irrigation systems, and so on. Agricultural development is the improvement of skills possessed by farmers that were not possessed in the past. Agricultural development will succeed if:

1. There is a market for agricultural products

2. Technology that is constantly developing

3. Availability of materials and production equipment locally

4. Production for farmers

5. Availability of smooth and continuous transportation (Mosher 1984) 
Other Mosher opinions are:

1. Educational development

2. Farmers' cooperation activities

3. Improvement and expansion of agricultural land

4. National planning of agricultural development Factors of production are:

1. Capital

2. Seeds

3. Soil fertility

4. Labor

5. Working hours

6. Fertilizer

7. Irrigation system

8. Land area

9. Pesticides

10. Intensive management.

Food security is the ability of a nation to fulfill/guarantee food sufficiency for the entire population. One indicator of measuring food security is the dependence of food availability on imports (R \& D Ministry of Agriculture 2005). Of Law No. 18 of 2012 concerning food, food security is the condition of the fulfillment of food for the state to the individual, which is reflected in the availability of sufficient food, both in quantity and quality, safe, diverse, nutritious, equitable, and affordable and does not conflict with religion, beliefs and culture community, to be able to live healthy, active and productive sustainably.

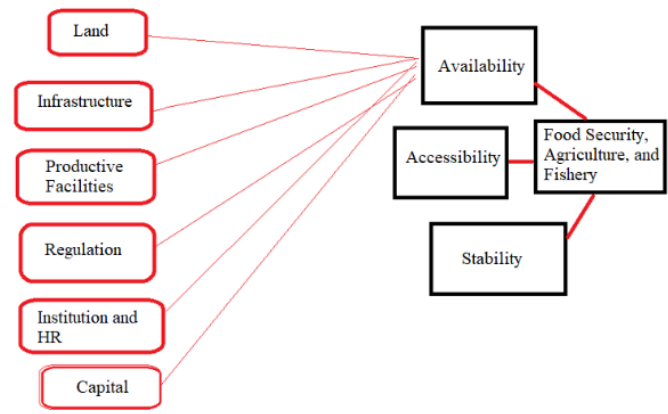

Figure 1. Fishbone Food Security, Agriculture, and Fishery of Law No. 18 of 2012

\section{RESEARCH METHODS}

The time of this research was from June 2018 to July 2019. The submission of proposals and acceptance was from June 2018 to December 2018. Focus Group Discussion for researchers was from January to March 2019. The field implementation is from April to July.
This research uses quantitative research and qualitative research. The quantitative research method is descriptive quantitative which uses list closed question with percentage results; meanwhile, the qualitative research methods is document literature, the unstructured interview to several farmer groups and held FGD to discuss the problems of Food Security. This research is accompanied by Food Security, Agriculture, and Fishery Agents from South Tangerang City and Banten Province.

This section at least consists of a description of article methodologies such as the technique of data collection, the data analysis, and variable measurement.

To get objective data, in this discussion, researchers used a data collection method with the following steps:

\section{Observation}

Observation is an attempt to obtain and infer day by making direct observations in the field of an accurate activity and reporting on the phenomenon that arises and considering the relationship between aspects of the phenomenon.

To ensure the phenomenon, we visited Food Security, Agriculture, and Fishery Agency South Tangerang City to dig information. Secondly, we visited a friendship event. Fourthly, we prepared structural questions for them.

The structural questions are as follows:

1. Land

a. Limited land

b. Degradation in land quality

c. Uncertainty of ownership status

d. Change of function from productive land to consumptive

2. Infrastructure

a. Irrigation networks and reservoirs

b. Garden laboratories and breeding cages of seeds and seeds

c. Consultation clinic for plant and animal resilience

d. Workshop as an information centre, promotion and counselling

3. Production Facilities

a. The lack of quality superior seeds, fertilizers, feed and pesticides

b. Limitations of agricultural equipment and machinery to the level of farming

c. Less than optimal function of an institutional service provider of production facilities 
d. The lack of development of seed breeding business

4. Regulation

a. Overlapping regulations

b. Regulations that do not favour farmers, such as the determination of grain basic-price (HPP)

c. There is no synergy between programs to increase productivity, expansion of plant areas, safeguarding production from disturbance of disturbing plant organisms, impacts of climate change and loss of yield during harvest and post-harvest, institutional and financing improvements

d. The regulation of government No. 38 of 2007 is not well guarded

5. Institution and HR

a. Institutions of farmers who do not have a strong bargaining position

b. The limitations of farmers in the use of technology

c. Decreased interest in the younger generation in the fields of food security, agriculture, and fisheries

d. Less institution is concentrated in this field

6. Capital

a. Law No. 19 of 2013 did not go as expected

b. The lack of bank credit for the interests of Food and Energy Resilience, Credit for Vegetable Energy Development and Revitalization of Plantations, Cattle Breeding Business Loans, and credit schemes such as People's Business Credit

c. Administrative factors that complicate farmers

d. Capital is not according to needs

\section{Documentation Study}

Documentation studies, namely research collected, read, and analyzed various data taken from BPS and South Tangerang City Agriculture and Fisheries Food Security Agency.

\section{FGD (Focus Group Discussion)}

Focus Group Discussion (FGD) is the term focus group discussion and is currently very popular and widely used as a method of collecting data in sausage research. Qualitative data collection through the FGD is widely known for its advantages in providing convenience and opportunities for researchers to establish openness, trust, and understand perceptions, attitudes, and experiences of respondents/participants.
As a research method, the FGD is a systematic effort to collect data and information. FGD uses 3 keywords:

a. Discussion - not interview or chat

b. Groups - not individuals

c. Focused - not free

The problems discussed in the FGD are very specific because they fulfill clear objectives. Therefore, the questions compiled and submitted to the FGD participants are clear and specific. The FGD was conducted to focus on the depth of information but could not be generalized. Through FGD, researchers can find out the reasons, motivations, arguments or basis of a person's or group's opinions. In other words, the FGD cannot be used as a conclusion from the results of the research. This must be added to other supporting data or conducting surveys.

The number of participants in the FGD is the most important factor that must be considered. According to some literature on FGDs (Sawson, Manderson \& Tallo 1993; Irwanto 2006; and Morgan DL 1998) the ideal number is 7 - 11 people, but there are also those who suggest a smaller number of participants, 4 - 7 (Koentjoro 2005: 7) or 6-8 people (Krueger \& Casey 2000: 4) Too little does not provide interesting variations, and too many will reduce the opportunity of each participant to contribute deep thoughts. The number of participants can be reduced and added based on the research objectives and facilities available. Recruitment of participants is homogeneous or heterogeneous; related to the homogeneity or heterogeneity of FGD participants, Irwanto (2006: 75-76) put forward the following principles:

a. Selection of the degree of homogeneity or heterogeneity of participants according to the initial purpose of the FGD.

b. The more homogeneous the background and certain variables, there is no need for an FGD, but the more heterogeneous the FGD results will be too varied.

c. Homogeneity - heterogeneity depends on several aspects, namely, gender, socioeconomic status,

d. The religious background is homogeneous, but in carrying out heterogeneous small businesses, the group can still run well, and the FGD is still considered necessary.

e. The main consideration in determining homogeneity-heterogeneity is the characteristics that must / may / may not be heterogeneous, and which characteristics should / may / may not be homogeneous. 


\section{RESULTS AND DISCUSSION}

\section{Result}

Firstly, we have dug information from 4 instructors. Table 1 show:

Table 1. The Agricultural Instructors

\begin{tabular}{cc}
\hline Instructor & District \\
\hline I1 & Serpong \\
I2 & Pondok Aren \\
I3 & Setu \\
I4 & All-District \\
& (Representative \\
& Banten Province) \\
\hline
\end{tabular}

Secondly, we deployed structure questions to 30 members of females' farmers. Table 2 shows as following.

Table 2. Females' Farmer Groups

\begin{tabular}{cc}
\hline Farmers & Females' Farmer Groups \\
\hline FF1 & Bina Tani \\
FF2 & KWT Az-zahra \\
FF3 & KWT Az-zahra \\
FF4 & KWT Az-zahra \\
FF5 & KWT Az-zahra \\
FF6 & KWT Az-zahra \\
FF7 & KWT Az-zahra \\
FF8 & KWT Az-zahra \\
FF9 & KWT Az-zahra \\
FF10 & KWT Az-zahra \\
FF11 & KWT Az-zahra \\
FF12 & KWT Az-zahra \\
FF13 & KWT Az-zahra \\
FF14 & KWT Nusa Indah \\
FF15 & KWT Karya Ibu \\
FF16 & KWT Insani \\
FF17 & KWT 025 Puri Pamulang \\
FF18 & KWT 025 \\
FF19 & KWT 01 Pamulang \\
FF20 & KWT 01 Pamulang \\
FF21 & Poktan/KTNA \\
FF22 & KWT Serpong \\
FF23 & KWT Serpong \\
FF24 & KWT Mawar \\
FF25 & Dumay \\
FF26 & Dumay \\
FF27 & Dumay \\
FF28 & Dumay \\
FF29 & Dumay \\
FF30 & Serua Indah \\
\hline
\end{tabular}

Note: $F F=$ Female Farmer
Thirdly, Focus Group Discussion is attended as following:

Table 3. The Attendance's Focus Group Discussion

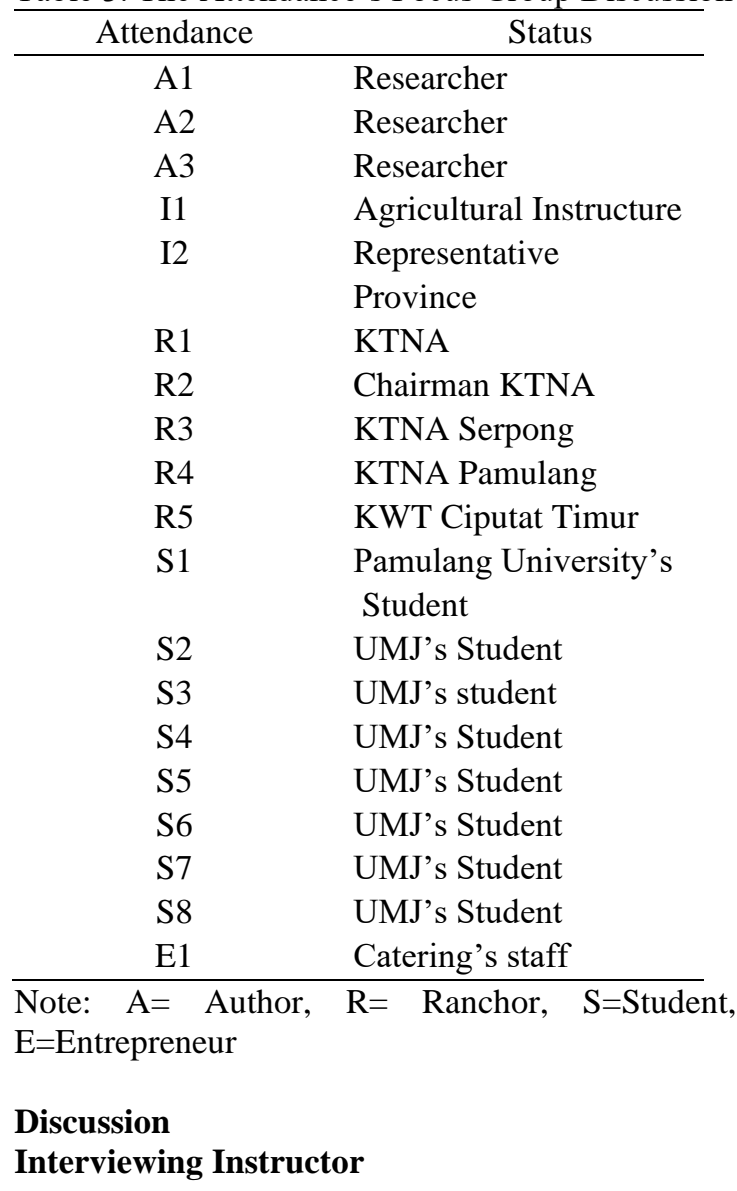

According to the instructor the barriers of Food Security, Agriculture, and Fishery have four concerns. First, the land in South Tangerang City has been owned by the developer about $70 \%$. Second, Many farmer groups are not yet incorporated. That condition makes government assistance for agricultural is difficult to allocate. Third, the local government's urban area usually is not a primary concern, so often; the regulation does not support the primary sector, such as agriculture and fishery.

The stimulations that are made by Food Security, Agriculture, and Fishery Agency are props, seed houses, and workshops. Bank Indonesia also subsidizes a thousand onion seeds to reduce the inflation rate. Third, the culture of citizen plant rice that is not for sale. Those support agriculture in South Tangerang City.

\section{Spreading questionnaires}

We construct indicators from Food Security, Agriculture and Fishery Agency's report which 
conclude six criteria and several indicators. The spreading questionnaires were in Event Friendship Buaran on June $18^{\text {th }} 2020$. These results are from 30 members of farmer groups in South Tangerang City. Table 4 is the results for question number one.

Table 4 shows the most crucial obstacles in South Tangerang City such as land is about 60\%; infrastructure is $0 \%$; production Facilities is $0 \%$; regulation is $0 \%$; institution and human resource are $0 \%$; capital is $30 \%$, and; others are $0 \%$.

Table 4. The Most Crucial Obstacles in South Tangerang City

\begin{tabular}{lr}
\hline \multicolumn{1}{c}{ Description } & Percentage \\
\hline Land & $60 \%$ \\
Infrastructure & $0 \%$ \\
Production Facilities & $0 \%$ \\
Regulation & $0 \%$ \\
Institution and HR & $10 \%$ \\
Capital & $30 \%$ \\
Others & $0 \%$ \\
\hline
\end{tabular}

Table 5 showing land constraints consist of limited land about $43 \%$, decrease quality of land about $0 \%$, the uncertainty of ownership status about $40 \%$, change of function from productive land to consumptive land, and others are $0 \%$.

Table 5. The Land Constraints

\begin{tabular}{lr}
\hline \multicolumn{1}{c}{ Description } & Percentage \\
\hline Limited land & $43 \%$ \\
$\begin{array}{l}\text { Degradation of land } \\
\text { quality }\end{array}$ & $0 \%$ \\
$\begin{array}{l}\text { Uncertainty of ownership } \\
\text { status }\end{array}$ & $40 \%$ \\
$\begin{array}{l}\text { Change of function from } \\
\text { productive land to } \\
\text { consumptive }\end{array}$ & $17 \%$ \\
Others & $0 \%$ \\
\hline
\end{tabular}

Table 6 showing the indicators of long-term infrastructure development priorities are irrigation networks and reservoirs about 13\%, garden laboratories and breeding cages of seeds about $47 \%$, consultation clinic for plant and animal resilience about $10 \%$, workshop as an information center, promotion and counseling about $30 \%$.

Table 7 illustrates the production facilities constraints. It has indicators which are the lack of superior quality seeds, fertilizers, feeds, and pesticides about $40 \%$, limitations of agricultural equipment and machinery to the level of farming about $20 \%$, less than optimal function of an institutional service provider of production facilities about $20 \%$, the lack of development of seed breeding business about $13 \%$ and the others are $7 \%$.

Table 6. Long-term Infrastructure Development

\begin{tabular}{lr}
\multicolumn{1}{c}{ Priorities } & \multicolumn{1}{c}{ Description } \\
\hline $\begin{array}{l}\text { Irrigation networks and } \\
\text { reservoirs }\end{array}$ & $13 \%$ \\
$\begin{array}{l}\text { Garden laboratories and } \\
\text { breeding cages of seeds }\end{array}$ & $47 \%$ \\
$\begin{array}{l}\text { Consultation clinic for plant } \\
\text { and animal resilience }\end{array}$ & $10 \%$ \\
$\begin{array}{l}\text { Workshop as an information } \\
\text { center, promotion, and } \\
\text { counselling }\end{array}$ & $30 \%$ \\
Others & \\
\hline
\end{tabular}

Table 7. Production Facilities Constraints

\begin{tabular}{lr}
\hline \multicolumn{1}{c}{ Description } & Percentage \\
\hline $\begin{array}{l}\text { The lack of superior quality } \\
\text { seeds, fertilizers, feed and }\end{array}$ & \\
pesticides & $40 \%$ \\
$\begin{array}{l}\text { Limitations of agricultural } \\
\text { equipment and machinery to the }\end{array}$ & \\
$\begin{array}{l}\text { level of farming } \\
\text { Less than optimal function of } \\
\text { the institutional service provider } \\
\text { of production facilities }\end{array}$ & $20 \%$ \\
The lack of development of & $20 \%$ \\
seed breeding business & \\
Others & $13 \%$ \\
\hline
\end{tabular}

Table 8 shows the constraints of the regulations in South Tangerang City. First, overlapping regulations are $23 \%$. Second, regulations that do not favor farmers, such as the determination of grain HPP are $0 \%$. There is no synergy among programs about $70 \%$. The rules of government number 38 of year 2007 are not well-guarded about $0 \%$. The others are $7 \%$.

Table 8. Regulation Constraints

\begin{tabular}{lc}
\hline \multicolumn{1}{c}{ Description } & Percentage \\
\hline $\begin{array}{l}\text { Overlapping regulations } \\
\text { Regulations that do not favour } \\
\text { farmers, such as the } \\
\text { determination of grain HPP }\end{array}$ & $23 \%$ \\
$\begin{array}{l}\text { There is no synergy among } \\
\text { programs }\end{array}$ & $0 \%$ \\
$\begin{array}{l}\text { PP No. } 38 \text { of } 2007 \text { is not well } \\
\text { guarded }\end{array}$ & $70 \%$ \\
Others & $0 \%$ \\
\hline
\end{tabular}


Table 9 describes institution and human resources constraints that are institutions of farmers who do not have a strong bargaining position, the limitations of farmers in the use of technology about $13 \%$, decreased interest in the younger generation about $67 \%$, and the others are $0 \%$.

Table 9. Institution and Human Resources Constraints

\begin{tabular}{lc}
\hline \multicolumn{1}{c}{ Description } & Percentage \\
\hline $\begin{array}{l}\text { Institutions of farmers who do not } \\
\text { have a strong bargaining position } \\
\text { The limitations of farmers in the }\end{array}$ & $7 \%$ \\
$\begin{array}{l}\text { use of technology } \\
\text { Decreased interest in the younger } \\
\text { generation }\end{array}$ & $67 \%$ \\
$\begin{array}{l}\text { The lack of institutions that are } \\
\text { concentrated in this field } \\
\text { Others }\end{array}$ & $13 \%$ \\
\hline
\end{tabular}

Table 10 showing capital constraints are that law number 19 of years 2013 did not go as expected $0 \%$, the lack of bank credit for the benefit of food security about $30 \%$, administrative factors that complicate farmers about $13 \%$, capital is not according to needs about $40 \%$, The others are $17 \%$.

Table 10. Capital Constraints

\begin{tabular}{lr}
\hline \multicolumn{1}{c}{ Description } & Percentage \\
\hline $\begin{array}{l}\text { Law No. 19 of 2013 did not go } \\
\text { as expected }\end{array}$ & $0 \%$ \\
$\begin{array}{l}\text { The lack of bank credit for the } \\
\text { benefit of Food Security }\end{array}$ & $30 \%$ \\
$\begin{array}{l}\text { Administrative factors that } \\
\text { complicate farmers }\end{array}$ & $13 \%$ \\
$\begin{array}{l}\text { Capital is not according to } \\
\text { needs }\end{array}$ & $40 \%$ \\
Others & $17 \%$ \\
\hline
\end{tabular}

\section{Focus Group Discussion}

On Monday, July 15, 2019 lecturers and researchers from the University of Pamulang, chaired by Iman Lubis S.E., M.S.M. and consists of Kholidah Tamami, S.I.P., M.Sc, and Rr. Mardiana Yulianti, S.S., M.Pd. held a focus group discussion with extension workers and agricultural activities throughout South Tangerang located at the Agricultural and Fisheries Counseling Center located at Jombang Jl. Saidih Jombang. The event starts at 10:00 to $12: 30 \mathrm{WIB}$.

\section{The land's Barrier and Solution}

The land barrier is the majority problem. According to R2 In the past, South Tangerang City had large rice fields that were private land, but water pollution destructed the land. That made the plant could not grow well. That was why the land sold to the developer.

However, there is solution. One of the farmer's groups has an agreement to ranch the unused land as long as 10 years or the land is built yet. Also, the unused land that is owned by the developer is about 10 hectares.

\section{The Infrastructures and Solution}

The problems of infrastructures are irrigations, workshops, seed houses, and coaching clinic plants and animals. Irrigation is the reason the rice field reduced. Only is a small area near clean water, and mostly the irrigations are from groundwater. Seed house is one of the program agencies in intensification. Couching clinic animals and plantation have been available in several places.

The problem of cultivation fish is that the water is polluted so cultivating in the natural river is impossible. Thus, the difficulty of cultivating freshwater fish also is constrained by the fish feed that is not provided by nature. Consequently, fish breeders must buy fish feed and the price increase continually. The infrastructure's land pond for cultivating catfish makes the different fish shapes. For example, the head is larger than a body that is different where the catfish breed in the freshwater in the river. These problems exist.

The competition is the best way to motivate a new farmer to join farming activities. Conversely, when the competition is over, the spirit of the ranch will be disappeared.

\section{Production's Facilities}

The production of facilities' barriers was denied as a problem by one of $\mathrm{R}$ because farmers did not ask them when they need the facilities. Also, The Agency has subsidized such as seed houses and tractors, but the subsidized fertilizer is difficult to get.

\section{The Regulation Constraints}

There are overlapping regulations. First, to buy the subsidized fertilizer needs minimum purchase, but for land, in South Tangerang City, the minimum buying does not fulfill. Second, Urban Planning is zero for farming. There is no perennial land in South Tangerang City. Perennial land is the land that has irrigation and production. 


\section{Institution and Human Resources Constraints}

The constraints are the younger generation and the administrative farmer groups. The next generation does not interest in agricultural fields, whereas, in South Tangerang City, the productive ages are larger than the elders. Almost farmer's ages are upper $50^{\text {th }}$.

Actually, farmer groups have positively impacted to develop farming. If the farmer group is incorporated, the farming activities will be subsidized by the government.

\section{Capital Constraints}

Since a long time ago, the capital constraint has been a problem. The problem of capital exists. Every farmer will be difficult to plant seeds or breed the fish. Thus, the urban farm is very expensive. Unfortunately, farmers have not followed the capital requirements, and legal entity proposed. Also, banking credit that handled for agriculture in the city is rare. Only one or two banks have lending programs for that.

\section{CONCLUSION}

In Conclusion, this research answers the facts of problems agriculture in South Tangerang City. First, land for farming is not owned by farmers. Second, the lack of infrastructures, such as irrigation and clean water for farmer and fish breeder support poor production. Third, production facilities such as superior seeds, subsidized fertilizer, seeds developers, and optimal institutions are very poor. Fourth, regulation in South Tangerang City cannot fully implement because farming activities is less than other areas. Fifth, the institution and human resources for supporting farming are less because of the lower quantity of youth and farmers group. Sixth, investment in South Tangerang City emphasizes housing rather than agriculture. The characteristic of South Tangerang City as a satellite city of Jakarta is used as a place of residence, and many citizens work in Jakarta.

From this research, we emphasize three obstacles, which are important that are land, capital, institutional and human resources. The main problem of land is limited land; the bulk problem of institutional and human resources is a decreasing young generation to work in farming, and the problem of capital does not fill the needs. Also, in Focus Group Discussion, the findings of problems are that limited land can be fixed by agreement to Developer; meanwhile, institutional and human resources are still dilemmas because the farmers from years to years decreased. To stimulate them, the agency supports the farmer group competition and seed house, but we all know that is not enough to increase the quantitative of farmer groups and institution. Those can be further research.

\section{ACKNOWLEDGMENTS}

This research was fully supported by the Higher Education and Research Technology Ministry, Beginner Lecturer Research Granting, IDR $13,630,000$.

\section{REFERENCES}

Arikunto, S. (1990). Prosedur Penelitian Suatu Pendekatan Praktek. Jakarta: Rineka Cipta.

Badami, G., \& Ramankutty, N. (2015). Urban agriculture and food security: A critique based on assessment o urband land constraints'. Global Food Security, 4, 8-15.

Bappenas. (2014). Penyusunan RPJMN 2015-2019 Bidang Pangan dan Pertanian. Retrieved July 5, 2019, from https://www.bappenas.go.id/files/1914/429 9/8417/Penyusunan_RPJMN_20152019_Bidang_Pangan_dan_Pertanian

Bungin, B. (2007). PENELITIAN KUALITATIF Komunikasi, Ekonomi, Kebijakan Publik, dan Ilmu Sosial Lainnya Edisi Kedua. Jakarta: Kencana.

Dawson, S., Manderson, L., \& Tallo, V. L. (1993). A manual for the use of Focus Group. Boston: International Nutrition Foundation For Developing Countries (INFDC).

Endraswara, S. (2003). Metodologi Penelitian Kebudayaan, . Yogyakarta: Gadjah Mada University Press.

Hamidah, S., \& Sartono, A. (2017). Perbedaan Pola Konsumsi Bahan Makanan Sumber Protein di Daerah Pantai, Dataran Rendah dan Dataran Tinggi. Jurnal Gizi, 1(6).

Heryawan, A., \& Fauzi, A. (2014). Analisis Ekonomi dsan Kebijakan Jawa Barat. Journal of Agriculture, Resource, and Environmental Economics, 2, 1-11.

Ika, A. (2018, 04 03). Kompas. Retrieved 0601 , 2019, from ekonomi.kompas.com: 
https://ekonomi.kompas.com/read/2018/04/ 03/140000126/19-4-juta- indonesian people-can't-fulfil-food-needs? page $=$ all .

Ilham, N., Siregar, H., \& Priyarsono, D. S. (2016). Efektivitas kebijakan harga pangan terhadap ketahanan pangan. Jurnal Agro Ekonomi, 24(2), 157-177.

Indonesia. (n.d.). Peraturan Pemerintah Republik Indonesia Nomor 38 Tahun 2007 tentang Pembagian Antara Pemerintah, Pemerintah Daerah Provinsi, dan Pemerintah Daerah Kabupaten dan Kota. Indonesia.

Indonesia. (n.d.). Undang-Undang Ketahanan Pangan Nomor 18 Tahun 2012. Indonesia.

Indonesia. (n.d.). Undang-Undang Nomor 45 Tahun 2009 Tentang Perikanan.

Indonesia. (n.d.). Undang-Undang Republik Indonesia Nomor 19 Tahun 2013 Tentang Perlindungan dan Pemberdayaan Petani. Indonesia.

Irwanto. (2006). Focus Group Discussion (FGD) : Sebuah Pengantar Praktis. Jakarta: Yayasan Obor Indonesia.

Karini, D. M. (2013). Dampak Alih Fungsi Lahan Persawahan Terhadap Produksi Beras Dalam Rangka Ketahanan Pangan (Studi Kasus di Kabupaten Tangerang). Jurnal Ketahanan Nasional, 19, 1.

Koentjoro, N. (2005). Metode-metode Penelitian Masyarakat. Jakarta: PT Gramedia Pustaka Utama.
Morgan, D. L. (1998). Practical Strategies for Combining Qualitative and Quantitative Methods: Applications to Health Research. Qualitative Health Research, 8(3), 362-367.

Mosher, A. T. (1984). Menggerakkan dan membangun pertanian: syarat-syarat pokok pembangunan dan modernisasi. Jakarta: CV Jasaguna.

Octavian , A. (2012). Militer dan Globalisasi: Studi Sosiologi Militer dalam Kontes Globalisasi dan Kontribusinya bagi Transformasi TNI. Jakarta: UI Press.

Phillips, M., \& etal. (2015). Exploring Indonesian aquaculture futures. Retrieved Juni 1, 2019, from

https://pubs.iclarm.net/resource_centre/201 5-39.pdf

Poerwandari, E. K. (2011). Pendekatan Kualitatif untuk Penelitian Perilaku Manusia. Depok: LPSP3.

Syahza, A., \& Suarman, S. (2017). Model pengembangan daerah tinggal dalam upaya percepatan pembangunan ekonomi pedesaan. Ekuitas (Jurnal Ekonomi dan Keuangan), 18(3), 365-386.

Virgantari, F., \& al, e. (2017). Analisis Permintaan Ikan di Indonesia: Pendekatan Model Quadratic Almost Ideal Demand System (Quaids). Jurnal Sosial Ekonomi Kelautan Dan Perikanan, 6(2), 191-203. 
This page is intentionally left blank 